Sustinere

Journal of Environment and Sustainability

Volume 5 Number 1 (2021) 9-24

Print ISSN: 2549-1245 Online ISSN: 2549-1253

Website: https://sustinerejes.com E-mail: sustinere.jes@iain-surakarta.ac.id

\title{
RESEARCH PAPER \\ Waste management of traditional dairy farming for alternative energy: A feasibility study on biogas processing in Dusun Banyudono, Semarang Regency, Indonesia
}

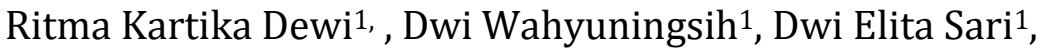 \\ Setia Humani Jatiningrum ${ }^{1}$, Widhi Handayani ${ }^{*}$ \\ ${ }^{1}$ Fakultas Ekonomika dan Bisnis, Universitas Kristen Satya Wacana. Jl. Diponegoro 52-60 Salatiga 50711, \\ Central Java, Indonesia \\ ${ }^{2}$ Fakultas Interdisiplin, Universitas Kristen Satya Wacana. Jl. Diponegoro 52-60 Salatiga 50711, Central Java, \\ Indonesia \\ Article history: \\ Received May 22, 2020 | Accepted August 19, 2020 | Available online April 30, 2021
}

\begin{abstract}
Dairy farming's waste contributes to greenhouse (GHG) gas emission, and its conversion into biogas is of potential benefit to reduce emission while providing alternative energy for the dairy farmers. Although biogas conversion has been conducted in Banyudono, Semarang Regency, not all dairy farmers are interested in this biogas processing, and it seems to be related to the question of the benefit they would receive. This research aims to explain the management of the waste of dairy farming in Banyudono and a feasibility study on dairy farming in Banyudono, if biogas processing is not to be included and along with biogas processing. This study combines qualitative and quantitative approaches by conducting interviews, direct observation, documentation, and a feasibility study on biogas processing. This study finds that $8,400 \mathrm{~kg}$ of cow manure and 4,950 liters of urine are produced every day, by only $5.76 \%$ is processed into biogas, $11.25 \%$ is processed into manure, while $82.98 \%$ of the waste is left unused. The feasibility study indicates that biogas processing tends to increase the benefit received by independent farmers instead of the member of the dairy farmer group discussed in the study. Furthermore, our study reveals issues regarding the dairy farmers' environmental awareness, poor management of biogas distribution on the farmer group level, and technology adoption problems. Finally, a model of integrated farming system is composed to address the issue of waste management in Banyudono.
\end{abstract}

Keywords: biogas; feasibility study; traditional dairy farming; waste management

\section{Introduction}

Dairy farming waste is generally used only as fertilizer for agricultural management and brings additional income for the farmers. Despite its positive impact on dairy farmers, this

*Corresponding author. E-mail: widhi.handayani@uksw.edu DOI: https://doi.org/10.22515/sustinere.jes.v5i1.117 
business also has a negative impact due to the waste produced, particularly from the feces and urine. Livestock is one of the biomass producers in the form of liquid and solid waste, which can releases methane, and consequently, it increases greenhouse gases emission (Sunarto et al., 2012). This is in line with the research of Chadwick et al. (2011), who reported that cow manure contributes to the high emission of greenhouse gases (GHG). In Indonesia, Java is the highest contributor of GHG by emission rate of $30,100.86 \mathrm{GgCO}_{2} \mathrm{e} /$ year, and cow farming contributes the highest GHG by 11,684.4 $\mathrm{GgCO}_{2} \mathrm{e} /$ year (Nurhayati \& Widiawati, 2017).

Currently, the energy crisis becomes a global issue, including in Indonesia, particularly because of the imbalance between the supply and demand aspects. According to Liun (2015), Indonesia's energy profile to the year 2030 is increasing, with the highest growth comes from transportation (8.7\%), followed by industry (5.8\%), and commercial (5\%). Nevertheless, there will be a change in the supply side because the oil supply is decreasing over time. It is projected that the market share of oil will decrease from $34 \%$ in 2010 to $21 \%$ in 2030 , while the market share of coal is projected to increase from $13 \%$ in 2010 to $22 \%$ in 2030, in addition to other energy sources such as gas and renewable energy (Liun, 2015). However, the need to develop alternative energy in order to fulfill the community's need for energy at a reasonable price is increasing, particularly in many countries (Nurmalina \& Riesti, 2010). The Indonesian government targets to increase the electricity consumption per capita to 2,035 kWh and 3,201 kWh by business as usual and intervention scenarios by 2030 (Ministry of National Development Planning of Indonesia, 2019). In this context, the local government plays a role in identifying the gap in affordable energy to vulnerable groups in the community (UCLG, 2018). In regard to pursuing the goal, the government puts an effort to develop new technologies for new and renewable energies from bioenergy, water, wind, solar, tidal wave, and wind (Ministry of National Development Planning of Indonesia, 2019).

Among many kinds of bioenergy, bioenergy production in the rural area for households (Gabisa \& Gheewala, 2019) is potential to develop. Indonesia's rural community relies mostly on agriculture to fulfill their daily needs, and the community often raises livestock along with their farming activities. It is estimated that more than $88 \%$ of the Indonesian community works as farmers and livestock farmers (Lakitan, 2019), including dairy farmers. It is reported that a dairy cow contributes methane by $31 \mathrm{~kg} /$ year from its manure management and $61 \mathrm{~kg} /$ year from its digestion, which is the highest amongst all livestock (IPCC, 2006 in Nurhayati IS \& Widiawati, 2017). It implies the possibility of cow manure processing. In addition to reducing GHG emission, cow manure processing has the potential to produce alternative energy in the form of biogas and bring additional value to the dairy farming business.

Studies on dairy waste processing have been conducted by researchers, particularly in regard to its processing to organic fertilizer (Arsanti, 2018), sustainable farming, and integrated farming system (Herdian et al., 2013; Purnaningsih et al., 2014; Suhartanto et al., 2015; Syamsu, 2010), and conversion to biogas. Related to biogas, the studies that have been conducted were feasibility studies (Maktub et al., 2019; Wahyuni \& Amiruddin, 2009) and the eco-indicator of biogas (Muradin et al., 2018). Nevertheless, most of the studies are conducted by one qualitative or quantitative method, which is different from this study. The combination of qualitative and quantitative methods can complete each other in order to provide a more comprehensive description of the dairy farming waste management. Furthermore, this research provides 
information on comparison of biogas processing conducted by the farmer group and individual farmer.

Banyudono, a small sub-village in Gedong village of Banyubiru subdistrict, lies in Semarang regency, Central Java. Currently, some of the dairy farmers participate in a farmer group called Kelompok Tani Ternak (KTT). However, there were independent dairy farmers or farmers who do not participate in the farmer group. Our preliminary study showed 30 households processed cow manure for biogas. However, there are many more farmers who do not yet participate in biogas processing. Their reluctance is possibly related to their understanding concerning the benefit of biogas processing, which they are not sure to receive. Therefore, this research aims to explain the management of the waste of dairy farming in Banyudono; the feasibility of dairy farming in Banyudono if biogas processing is not to be included; and the feasibility of dairy farming in Banyudono along with biogas processing.

\section{Methods}

This research was conducted in Banyudono, Gedong village, Banyubiru subdistrict of Semarang Regency (Fig. 1). Based on our preliminary observation, the total inhabitants of this subvillage were 574 people and equal to 140 households; 135 households of which or about $96 \%$ of total households were dairy farmers, while the rest worked as the middleman for agricultural products. Banyudono sub-village has potential in the agricultural sector with the largest number of dairy cows (Harianingsih et al., 2018). Wijayanto (2012) once conducted community empowerment in the Banyudono sub-village to train and assist the villagers in replacing the use of chemical fertilizers by processing animal manure and rice straw into organic fertilizer.

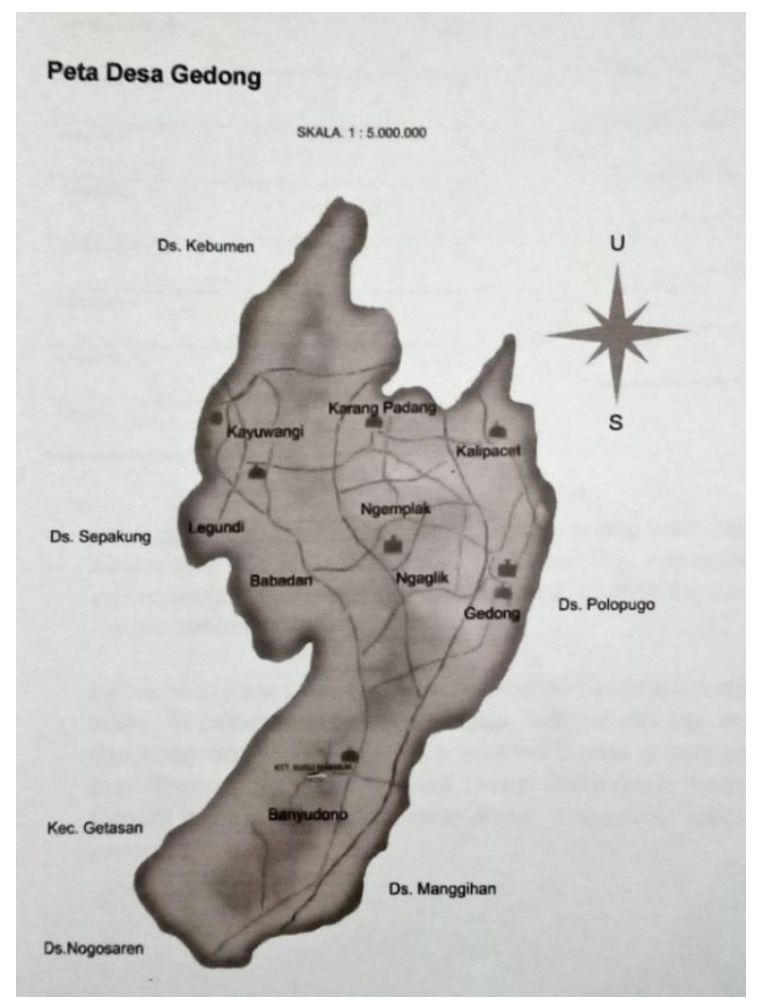

Figure 1. Administrative map of Gedong Village, Semarang Regency (source: Buku Profil Kelompok Tani Ternak Susu Makmur [unpublished]) 
Our preliminary observation showed there were 300 dairy cows in Banyudono, which produced feces and urine of $8400 \mathrm{~kg}$ and 4950 liters per day, respectively. As previously explained, if a dairy cow manure can contribute methane of $31 \mathrm{~kg} / \mathrm{year}$ (IPCC, 2006 in Nurhayati \& Widiawati, 2017), 300 dairy cows will contribute about 9,300 kg methane emission per year, only from the manure. In addition to reducing emissions and pollution, if this dairy cow manure is not processed, this means a waste of energy because the processing of manure into biogas can provide alternative energy to meet the energy needs of the Banyudono villagers. This is the reason for conducting this research in the Banyudono sub-village.

This research is a case study that involves two qualitative and quantitative approaches to address the study's aims. According to Yin (2003), a case study can be used when the research question focuses on "how" or "why", which implies the need for explanation. This strategy also focuses on contemporary events instead of historical events and does not need to control behavioral events. Regarding that, this study focuses on explaining the dairy farming business in Banyudono, and this study cannot control the behavior of the research subjects. Therefore this strategy is suitable for the topic of this study.

In this study, the qualitative approach was used to address the aim related to the management of dairy farming wastes in Banyudono. The quantitative approach was used to address the questions related to the feasibility study of the dairy farming business. The data for this study consists of primary and secondary data. Primary data was collected through in-depth interviews, observation, and documentation. The secondary data was collected from literature and data from Bank Indonesia to determine the rate of interest. In case that this study is conducted mainly by the qualitative method by case study, the conclusion of this study will be suitable only for Banyudono instead of a generalization.

Regarding the qualitative study, nine informants were involved, who consisted of the chief of the sub-village (Kepala Dusun) and eight dairy farmers. The dairy farmers interviewed operate biogas installations on a scale of $4 \mathrm{~m}^{3}$ and $36 \mathrm{~m}^{3}$. Considering that some dairy farmers are the member of KTT, and some others are independent farmers, the interviews were conducted to the farmers derived from those groups. The interview for each informant was done for 75 minutes. Data was collected for transcription and descriptively analyzed. The result is presented in narrative form, and the name of the informants, dairy farmer groups, and the Koperasi are replaced by pseudonyms to protect their privacy.

The feasibility of the dairy farming business, including waste management, was analyzed using Business Feasibility Analysis (BFA) according to Nurmalina \& Riesti (2010). The data collected from interviews and observation were used to calculate the BFA components, i.e., Net Present Value (NPV), Internal Rate of Return (IRR), Net Benefit-Cost Ratio (Net B/C), and Payback Period using the following equations.

$$
\mathrm{NPV}=\sum_{t=1}^{t=n} \frac{B t-C t}{(1+i)^{t}}
$$

Where, $N P V$ is net present value, $B t$ is total benefits obtained in the t-year, $C t$ is total costs incurred in the t-year, $I$ is discount rate, $N$ is project lifespan, and $t$ is year. 


$$
I R R=i_{1}+\frac{N P V_{1}}{\left(N P V_{1}-N P V_{2}\right)}\left(i_{2}-i_{1}\right)
$$

Where, IRR is internal rate of return, $i_{1}$ is interest rate on positive NPV (\%), $i_{2}$ is interest rate on negative NPV (\%), $N P V_{1}$ is positive NPV value, , $N P V_{2}$ and negative NPV value,

$$
\text { Net } \frac{\mathrm{B}}{\mathrm{C}} \text { Ratio }=\sum_{t=0}^{t=n} \frac{B t-C t}{(1+i)^{t}}
$$

Where, Net B/C is net benefit-cost ratio, $B t$ is benefits obtained in the $t$-year, $C t$ is costs incurred in the $t$-year, $n$ is the economic age of the project, $i$ is interest rate, and $t$ is investment rate.

$$
P P=\frac{I}{A b}
$$

Where, $P P$ or payback period is time period for capital return, $I$ is initial Investment, and $A b$ is of net benefit per year.

\section{Results and Discussions}

This section will discuss the management of dairy farming waste of Banyudono dairy farmers and evaluate dairy farming business feasibility involving biogas processing, using the cost-benefit analysis. Based on our preliminary study, we found the Banyudono community has started dairy farming since 2012. Previously, they relied on the production of paddy and vegetables to support their daily life. It indicates that there is a shift in the type of commodity they cultivate. Nowadays, about $96 \%$ of Banyudono farmers rely on dairy farming activities instead of cultivating paddy and vegetables.

\subsection{General description of dairy farming in Banyudono}

According to Pak Sura Naragupita, the chief of Banyudono, the total population of Banyudono was 574 people. The sub-village is divided into four neighborhoods, which is usually called Rukun Tetangga (RT). He estimated that $99 \%$ of Banyudono people work as farmers, and only eight people work as vegetable sellers. Surya explained that previously the people cultivated paddy fields to fulfill their daily life. However, in 2010, people decided to shift to dairy farming. It was resulted from the lack of water situation they faced because the water supply to Banyudono was reduced in terms of quantity, while on the other side, water was crucial for paddy field farming. Eventually, the people shifted to dairy farming, and the fields were planted with grasses to feed their cattle. Nevertheless, the shift to dairy farming was not solely motivated by the lack of water. The transition seemed to be motivated by financial benefit as dairy farming was considered to provide more benefits instead of paddy field farming.

"The progress of Banyudono before the transition to cattle raising was zero. After cattle [raising], the progress was getting better. There are large houses and easier access to Banyudono. After the change, [Banyudono] is more developed." (Nuri, November 14, 2019) 
Ibu Nuri's statement implies that the transition to cattle farming has brought economic improvement, which is identified with the construction of walled cement houses, better infrastructure, and better access to the sub-village. On the contrary, before the people turned to dairy farming, there was no improvement as indicated by the construction of wooden planks house since their previous days.

However, behind the benefits of dairy farming, there is also a negative impact on the environment resulting from economic activity related to the waste of dairy farming. At first, the people of Banyudono did not understand the waste management practices, and they just piled the cow manure up behind the cages or their houses. Surprisingly, people did not feel bothered by the smell of the manure, and it did not become a problem for the people. Even Pak Sarijo, one of our informants, explained that there were no people who protested this situation.

The situation explained by Pak Sarijo indicates that the smell of cow manure is not considered pollution or is not considered to bother others as there were no people who protested against this situation. It implies that cow manure's smell will be considered a problem and potential to trigger a conflict when there are people who voice their discomfort due to the situation. It shows how the people show little attention to environmental sanitation, as unprocessed cow manure does not merely create pollution but can also affect their health adversely.

According to Ham et al. (2016), environmental awareness consists of three aspects, i.e., cognitive, affective, and conative, which are related to knowledge, emotion, and behavior, respectively. Nevertheless, Mei et al. (2016) put the cognitive aspect as very important, as their writing is related to the level of intentional environmental behavior to individual cognitive level to environmental issues. In line with Du et al. (2018) and Ham et al. (2016), Mei et al. (2016) also emphasized the role of knowledge and affection as environmental perception, in addition to environmental behavior and attitude. In this case, the cognitive aspect might affect dairy farmers' behavior in Banyudono, considering that most dairy farmers graduated from primary school. From our understanding, level of education does not always related to environmental awareness, because the environmental knowledge can be accessed from everywhere. Furthermore, environmental knowledge does not always relate to formal education. It is common in some cities and towns in Indonesia for people to join environmental organizations, such as Bank Sampah, to process the garbage instead of just throw them away to the environment (Andrawina et al., 2019; Septiani et al., 2019). Our study found that there was no Bank Sampah in Banyudono. Therefore, in order to promote their environmental awareness and provide additional income from garbage processing, creating the Bank Sampah in Banyudono will be a promising step.

Nowadays, for about two years, the dairy farmers in Banyudono have operated biogas installation for alternative energy because of the government's initiative. The cow manure and urine are used as raw materials for biogas production. Based on our calculation, there is 484 $\mathrm{kg} /$ day of cow manure converted to biogas. Currently, dairy farming waste management in Banyudono is presented in Figure 2.

Based on Figure 2, it is clear there is $6,971 \mathrm{~kg}$ of cow manure per day, which cannot be processed due to a limited volume of biogas installation. Also, there is 2,953,5 L urine per day, which is not processed, and those wastes are subjected to dischargement. Figure 3 presents the 
effect of the dischargement of the wastes into the channel, which is flowing to the stream. The discharge of those wastes to the river or water body does not only affect the environment but is also potential to cause water-borne diseases, such as diarrhea and dysentery. Mateo-Sagasta et al. (2017) highlighted that the waste from livestock sectors, including manure, has a severe effect on water quality. In addition to zoonotic water-borne pathogens, the use of hormones, vaccines, and antibiotics for the last 20 years has been causing potential harm to human health, particularly because they flow from the farmyard to drinking-water sources via the streams.

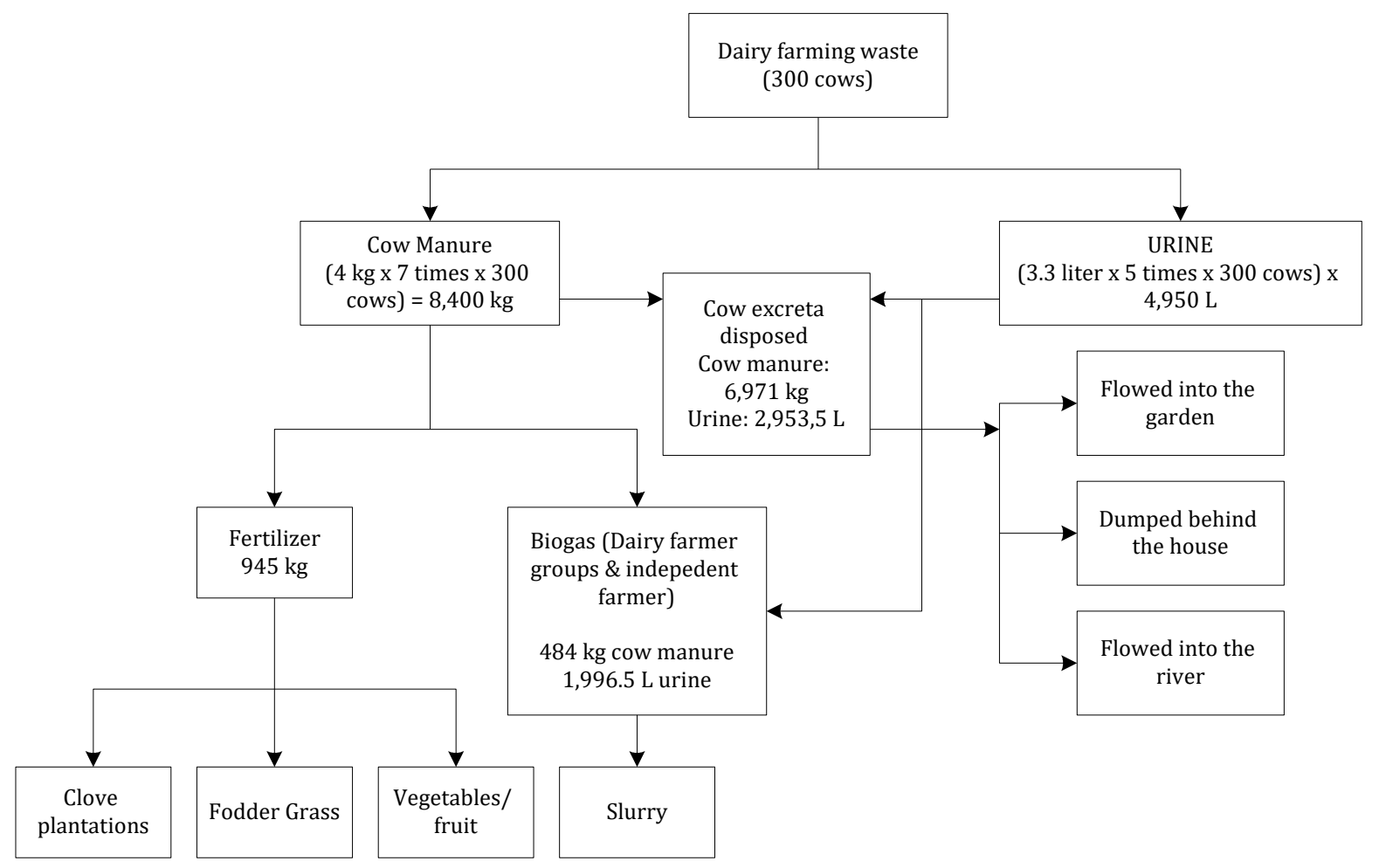

Figure 2. The current dairy farming waste management in Banyudono, Semarang Regency

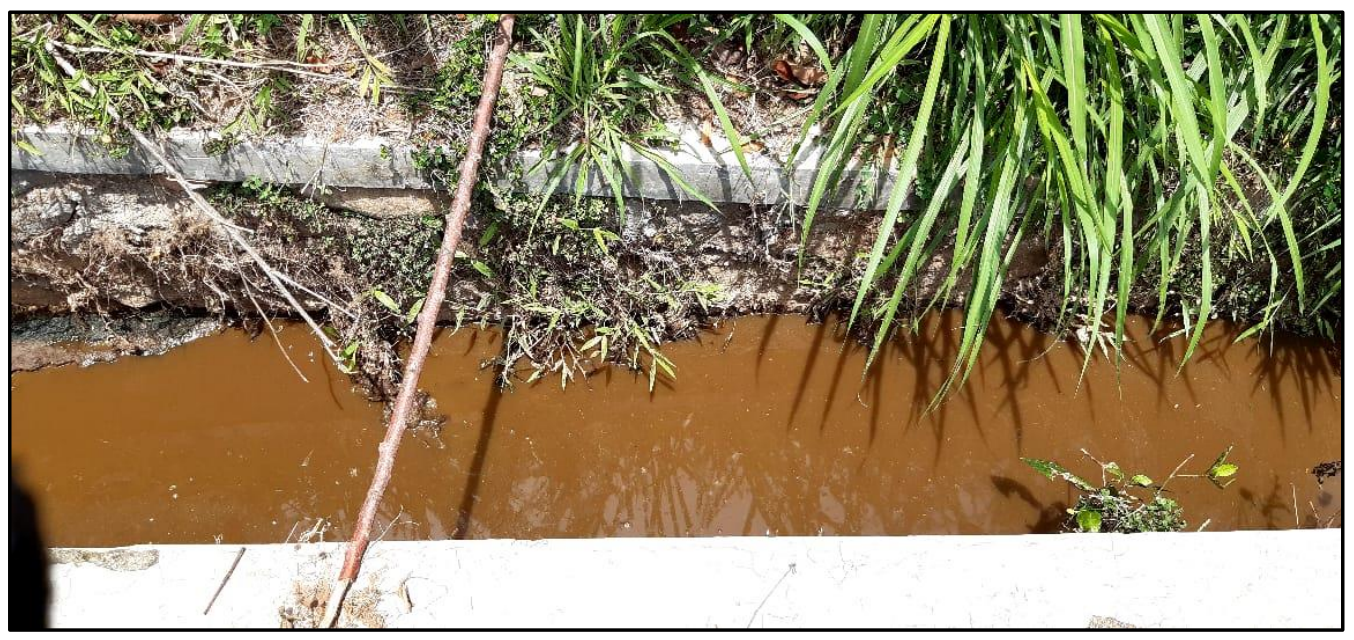

Figure 3. Waterbody (channel) where the excreta of dairy cows is usually disposed (source: documentation of authors, 2019) 


\subsection{Dairy farming management by dairy farmer group}

As Ahlberg-Eliasson et al. (2017) explained, biogas is produced from organic materials that digested anaerobically. This conversion brings some benefits, i.e. (1) reducing the GHG; (2) replacing fossil fuel; (3) the nutrients or slurry from the digestion, that can be processed into fertilizer (Ahlberg-eliasson et al., 2017). Cow manure production can reach $8,400 \mathrm{~kg} /$ day as there are about 300 dairy cows raised in Banyudono. As most manure cannot be used, it is then discharged into the stream behind the sub-village. Knowing this situation and considering the potential of dairy farming in Banyudono, the government took an initiative to convert the manure into biogas. This initiative was motivated by the interest to minimize the pollution of Rawa Pening lake, which was possibly caused by this manure because the nutrients contained in the manure can boost the growth of water hyacinth (Eichhornia crassipes), a well-known species of weed of Rawa Pening, as well as causing eutrophication.

There are three dairy farmer groups (KTT) in Banyudono, i.e., KTT Sriandini, KTT Srinandi, and KTT Setia Maju. This research focuses on the KTT Setia Maju by considering that this dairy farmer group is the largest among others as it operates three cages for dairy cows, and the total dairy cows raised by this group are 60 cows. Furthermore, this group is selected because the income of this group is sufficient to support its members. This group feeds its cows using feed concentrate for $8 \mathrm{~kg} /$ day and grasses for about $12 \mathrm{~kg} /$ day for a cow. The milk can be collected twice a day in a volume of about $800 \mathrm{~L}$ in total. The milk is usually sold to Koperasi Waluya Agung and Koperasi Nandi Ageng at a price of IDR 5,000 per liter of milk.

KTT Setia Maju put their biogas plants in three spots. The government constructed the permanent biogas digesters with a capacity of $36 \mathrm{~m}^{3}$ at the constructional cost of IDR $60,000,000$. Based on our observation and interview, these digesters are constructed in a dome style with concrete materials (Figure 4). This style of digester seems to fit the description of (Usack et al., 2014) the Chinese biogas digester model. After these plants are operated, the biogas produced can be used by eight households. The energy from the biogas is sufficient to support the daily activities of those households. If they hold more extensive activities, such as weddings and family gatherings, they still have to buy LPG to keep their energy needs.

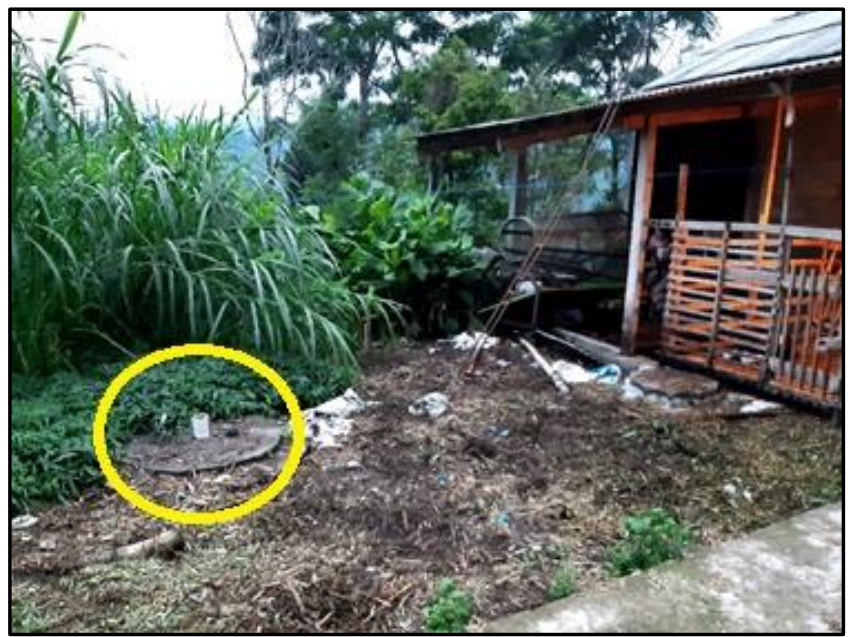

Figure 4. Permanent biogas digester (marked by a yellow circle) of Setia Maju dairy farmer group (source: documentation of authors, 2019) 
However, not all the group members have enjoyed the benefit even though they have participated in this group and fulfilled the group member requirement. Among 21 members, there are only eight members who can get the biogas. From their experience, all members can actually enjoy the biogas despite the long distance between their homes and the biogas plants. Nevertheless, there is pipe leakage that causes the gas to evaporate into the air, and hence the member cannot receive the gas distributed to their homes. They identified this by the fact that the stove cannot burn, although it is connected to the pipe of biogas plants. However, the trouble caused by leakage has not been resolved because of a technical issue that the soil buries the pipe, and they are unable to find the spot of the leakage. Their inability to solve this technical problem is not the farmer's fault, of course, because they do not have any competence in terms of knowledge and skills on how this know-how operates. While technology can help solve human problems on one side, the problem is not so simple in the case of adoption. Most technologies require specific knowledge and skills to operate, for their maintenance, and troubleshooting. As (Tonda \& Susan, 2015) explained, knowledge and skills being a challenge for technology adoption, particularly in countries where education levels in science, engineering, and technology are still low. However, this challenge may be addressed by building the community's capacity as the adopters or third-party operators entrusted to maintain the operational of biogas digester to reach its full potential (Bößner et al., 2019)

\subsection{Dairy farming management by independent dairy farmers}

The independent dairy farmers are farmers who do not participate in the groups. Their farmyards are planted by cow feed grasses and vegetables. Each farmer is usually raising 7-8 dairy cows, and their cows are fed by grasses, which is different to the Setia Maju members who provide their cows using the concentrate.

The independent farmers do not join the Setia Maju dairy farmer group because of some reasons. First, they think the rules of KTT Setia Maju are quite burdensome to them. One of the regulations requires the farmer to deposit grasses if they join the group. They also have to leave their cows in cages prepared by the group, while they have to maintain the cows by themselves. It places them in a troublesome situation because they have to maintain their cows, which are put in different places, i.e., some in their homes and the others in the cages of KTT. Putting focus and attention to take care of their cows in different areas consumes their time, and because of this, they decide not to join the KTT. They also think they receive no benefit from biogas management of the KTT, which is another reason for their unwillingness to join KTT.

Based on this result, it seems that the problem that hinders the participation of the farmers from joining KTT is mostly related to management issues, both regarding the rule of the group and the management of biogas distribution. Based on their study in Kenya, Fischer \& Qaim (2014) wrote that farmer participation in farmer groups is positively intensified by the previous benefit they receive from the group. Therefore, when the farmers think they get no benefit from the group, it is very likely that they will not join the group, which fits the situation in Banyudono. This is in line with Sandyatma \& Hariadi (2012) findings that participation of farmer group members in Penguatan Lembaga Distribusi Pangan Masyarakat -a capacity building conducted by the government- is mostly influenced by their income. Although other factors, such as age, intensity on receiving training information, and motivation influence farmers' participation, income is the most influential factor to their participation in capacity building and other farmer groups' activities. 
Independent dairy farmers built $4 \mathrm{~m}^{3}$ biogas digester using government support with a constructional cost of IDR 5,000,000 to IDR 6,000,000. This digester is made of plastic (Fig. 5), and the biogas produced can be used by 2-3 households. According to Usack et al. (2014), in addition to the Chinese digester model, there is also a Taiwanese digester constructed using polyethylene. While the fixed-dome model is more expensive and more complex, the latter is cheaper and easier to install in terms of its construction. However, its exposure to the sun directly over time is potential in causing its leakage (Usack et al., 2014). However, this digester has not been able to convert cow manure into biogas because its capacity is very limited.

In addition to the digester's capacity, another problem lies in the lack of investment to build the digester. As previously explained, the fixed dome price was about IDR 60,000,000, while the smaller digester could be constructed for about IDR 5,000,000. To the dairy farmers, the constructional cost of IDR 5,000,000 is quite expensive. Therefore, they rely on the government to build biogas digester up.

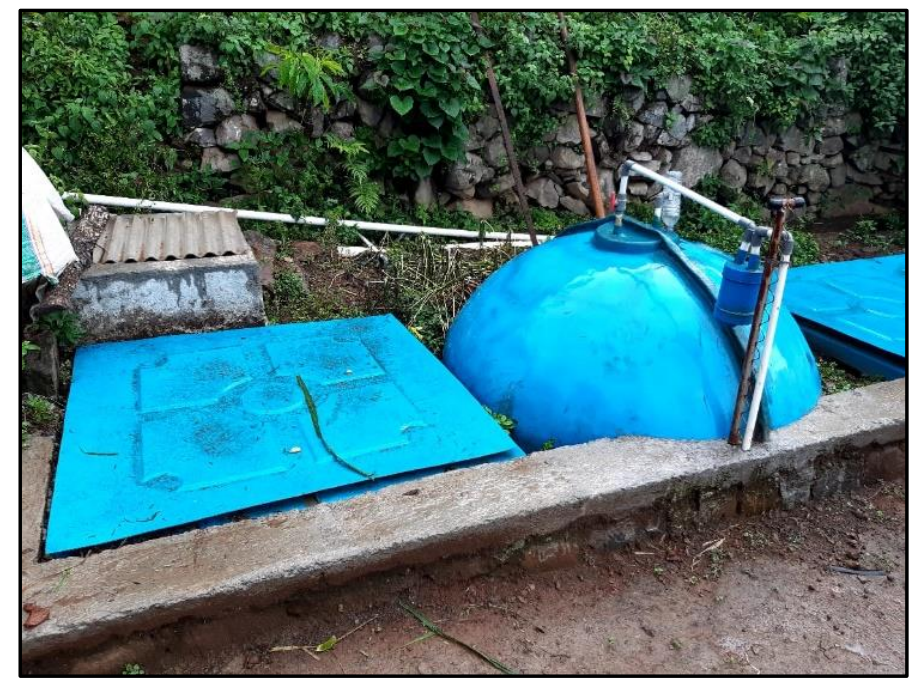

Figure 5. Biogas digester made of polyethylene applied by Banyudono dairy farmers (source: documentation of authors, 2019)

Furthermore, independent dairy farmers cannot build biogas digester because they only have a small number of cows. According to Ibu Tri Rahayu, one of our informants, they need five cows in minimum to process the cow manure into biogas. Actually, the rule of five cows in minimum is established by the KTT. Nevertheless, the dairy farmer adopts this rule as a minimum requirement that needs to be fulfilled if the dairy farmers want to install a biogas digester. Therefore, in order to build a biogas digester, dairy farmers must have at least five cows, must prepare investment, or they must be able to propose a biogas installation program to get supported by the government. Usack et al. (2014) have been improving the Indonesian digester model, which is constructed from PVC tubes to process manure from at least one cow, and the gas can be used for one-hour cooking on a stove. This research was conducted to improve the biogas digester that needs to fulfill some requirements, i.e., inexpensiveness, easiness to maintain, durability, and efficiency in converting manure into biogas (Usack et al., 2014). By this innovation, it is possible that the Indonesian biogas digester model can be provided at in much more 
affordable price in the future. Therefore, dairy farmers who raise cows in a number of less than five can produce biogas using a small-scaled digester at a more affordable price.

\subsection{Business Feasibility Analysis}

The calculation of business feasibility analysis was conducted by considering the value of NPV, IRR, Net BC, and Payback Period (Table 1). The condition of the investment feasibility of a business can be observed when the value of NPV> 0 , IRR $>$ discount rate (6\%), and Net B / C > 1 . The $6 \%$ discount rate refers to the interest rate used by Bank Indonesia at the beginning of 2020 . Our previous analysis showed that the dairy farming business in Banyudono, even without waste conversion into biogas, indicates the business is feasible to be carried out.

Table 1. Components of feasibility analysis of the Banyudono dairy farming

\begin{tabular}{lcccc}
\hline & \multicolumn{2}{c}{ No Biogas Processing } & \multicolumn{2}{c}{ Biogas Processing } \\
\cline { 2 - 5 } & $\begin{array}{c}\text { Farmer group } \\
\text { (KTT) }\end{array}$ & $\begin{array}{c}\text { Independent } \\
\text { farmers }\end{array}$ & $\begin{array}{c}\text { Farmer group } \\
\text { (KTT) }\end{array}$ & $\begin{array}{c}\text { Independent } \\
\text { farmers }\end{array}$ \\
\hline NPV (IDR) & $48,204,810.15$ & $43,188,188.54$ & $20,144,105.69$ & $86,757,909.62$ \\
IRR (\%) & 9 & 16 & 7 & 22 \\
Net B/C & 1.07 & 1.25 & 1.02 & 1.48 \\
Payback period (months) & 37 & 29 & 61 & 29 \\
\hline
\end{tabular}

Table 1 presents the feasibility analysis of dairy farming in Banyudono. It is presented that the NPV value is higher than zero, indicating that the incoming cash flow is greater than the costs to be incurred. Therefore, the difference becomes profit for a business. The business activities of 20 years of dairy farming business by a 6 percent discount rate provides the benefit of IDR $48,204,810.15$ for Banyudono farmer group members (KTT). In contrast, independent farmers will receive a profit of IDR $43,188,188,54$. Assume that the discount rate of the two businesses is of the same. After the biogas project is carried out, the level of profit obtained for the KTT drops to IDR 20,144,105.69 while the profit of independent farmers tends to increase to IDR $86,757,909.62$. The internal rate of the return value of the KTT also declines after the waste conversion into biogas, in opposite to that of independent farmers whose value tends to increase. The IRR value for independent farmers, which increases from $16 \%$ to $22 \%$, shows that the business is feasible because the investment value will result in a higher income than the initial target. In addition, the value of the net benefit-cost ratio also shows a similar result, as previously explained. The increase of net benefit/cost ratio of business run by independent farmers from 1.25 to 1.48 indicates that their business is feasible to run because the investment value will increase and higher than the initial target. Nevertheless, the net benefit/cost ratio of business run by KTT decreases from 1.07 to 1.02 between the use of biogas processing and without biogas processing.

The net benefit/cost ratio value shows the ratio of benefits received from each unit of the cost incurred. Even though the net benefit/cost ratio of both the KTT and independent farmers is higher than 1.0, the net benefit/cost ratio of independent farmers is higher than that of the farmer group's business. It seems that people of Banyudono will receive a greater additional benefit when they are independent farmers, and we argue, this is related to the number of beneficiaries. It is clear that in the current farmer group, there are only eight households who enjoy the biogas by 
IDR $60,000,000$ for investment. In other words, the initial investment made by the KTT members is substantial and makes the benefits received for KTT members are not worth compared to the benefits received. It can be seen from the Payback Period, which is longer than five years. The result also shows that the Payback Period for the KTT is not feasible when it is compared to the independent farmers because the IDR 60,000,000 investment for biogas by KTT requires a period of 61 months to return the investment, while the independent farmers require only 29 months for IDR 5,700,000 biogas investment cost. It means not all group members enjoy the biogas project's benefits, which is the reason behind the decline of the net benefit/cost ratio. On the other hand, the business run by independent farmers is conducted by a lower investment of IDR 5,700,000, which result can be enjoyed by three households. Suppose the management in biogas distribution of the KTT will be improved, and more members will benefit from the biogas. In that case, it is possible that the net benefit/cost ratio of the business will be increased.

A case study in Amhara proved that biogas could be used to replace current overall fuel consumption (Gabisa \& Gheewala, 2019). The size of the digester is possible to adjust the number of cows available in each region. According to Gabisa \& Gheewala (2019), a biogas digester of $8 \mathrm{~m}^{3}$ can reduce the use of wood fuel by $1,440 \mathrm{~kg}$. The results showed the Benefit-Cost Ratio, Net Present Value, PBP biogas digester size $8 \mathrm{~m}^{3}$ was better when compared to that of $6 \mathrm{~m}^{3}$. This is rather different from our result, which indicates the smaller biogas capacity tends to show a higher net benefit/cost ratio. Nevertheless, the study of Gabisa \& Gheewala was focused on the biogas application for the community instead of farmer groups. Although the net present value of $8 \mathrm{~m}^{3}$ digester was ETB 17,202, and ETB 12,952 for $6 \mathrm{~m}^{3}$ digester, the return on investment of $8 \mathrm{~m}^{3}$ biogas digester tends to take more time compared to that of $6 \mathrm{~m}^{3}$ digester, i.e., 2.38 years.

Using cost-benefit analysis, research of Mohammed et al. (2016) indicates that biogas capacity of $9000 \mathrm{~m}^{3}$ results in NPV values of more than zero, which means that the additional benefits received are greater than the costs incurred. A benefit/cost ratio value indicates that every $\$ 1$ will benefit $\$ 5.19$. From the studies, it is clear that the conversion of waste into biogas will benefit people in general. Therefore, this effort is recommended to realize, with consideration on improving the management of biogas distribution on the level of farmer groups.

In comparison to this study, Maktub et al. (2019) reported that the biogas installation from an agroindustry business with 9,000 cows could generate electrical energy for 204 customers with 1,300 VA electricity. Furthermore, the results indicated a positive NPV, the IRR was greater than the discount factor of $12.5 \%$, and the Net B / C value was greater than 1.0. All of the results recommended the feasibility of the biogas project for implementation. However, the biogas project's sensitivity analysis indicated that the project was not feasible if the maximum raw material produced by the farmers was $23 \%$ per year. This result is in line with our study in the term that the biogas processing is feasible to implement.

Research conducted by Wahyuni \& Amiruddin (2009) indicated that the biogas installation project is very feasible to be implemented by an NPV value of Rp. 39,370,074 (for individual farmer) and Rp. 6,184,621,541 (for group farmers). The study indicated a Net B/C value at a $17 \%$ discount rate was 2.14 (for individual farmers) and 50.13 (for group farmers). It means that the net income earned would be 2.14 and 50.13 times higher than the costs incurred. The research also showed that the IRR value resulted was 34\% (for individual farmers) and 90\% (for group farmers), indicating that if the government invested its money in this project, it would benefit. Nevertheless, 
the study implied that the group biogas installation project was feasible to use by both individuals and groups. This is different from our findings, indicating that biogas processing is more feasible for individual farmers than group farmers. Nevertheless, we have explained previously the reason behind the unwillingness of the farmers to join KTT. In addition to inequality and rules of the group (La Ferrara, 2000), the benefit they will receive (Fischer \& Qaim, 2014), and their income (Sandyatma \& Hariadi, 2012) are some factors that influence farmer's participation in farmer groups.

Finally, regarding waste management in Banyudono, another system on dairy farming waste management is presented in Figure 6. In this scheme, the processing of all wastes into biogas is proposed, including the cow manure, which formerly is used as fertilizer. Considering that natural composting is still causing emission, it is recommended that all cow manure be processed into biogas using new biogas installations to minimize the emission. In the next step, the slurry that comes from the process can be processed further into compost or organic fertilizer for clove plantations, fodder grass, and vegetables or fruit cultivation.

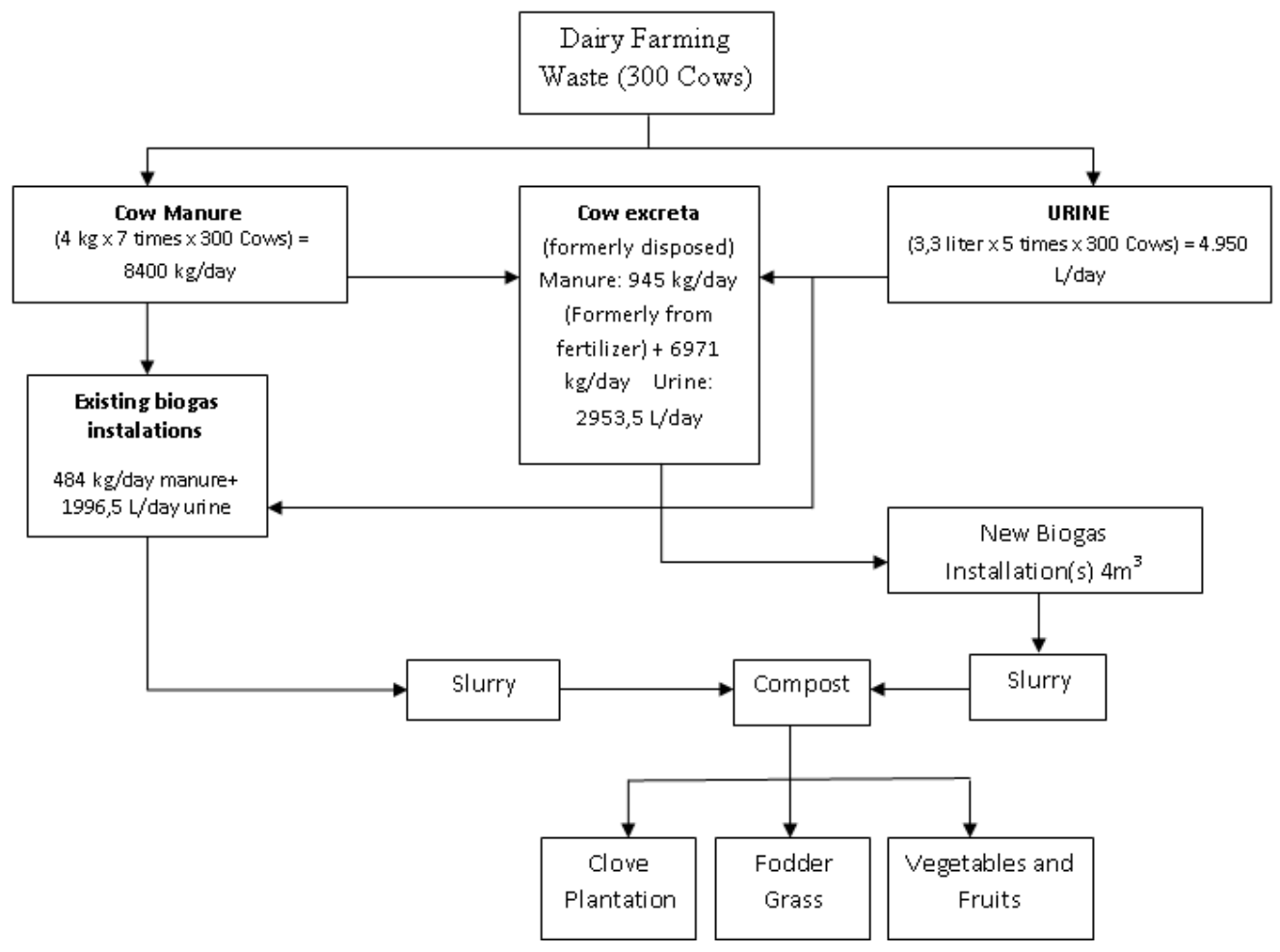

Figure 6. The proposed system for dairy farming waste management in Banyudono

Implementation of this system can bring some advantages in terms of reducing waste and reducing emissions. Conversion of waste into biogas means maximizing energy input productivity and minimizing pollution, which fits the concept of cleaner production (International Labor Office, 2013). This system also fits the circular economy concept, focusing on increasing the efficiency of resource used and reducing waste and emission through the circular cycle rather than a linear make-use-dispose system (Geissdoerfer et al., 2017). In addition, the composting of the slurry into organic fertilizer will bring additional value, as the fertilizer is possible to sell or used for farming. 
The production of organic fertilizer is also possible to replace or reduce the use of chemical fertilizer.

\section{Conclusion}

This study finds that the traditional dairy farming management in Banyudono still has to face some challenges related to environmental awareness, biogas distribution management at the farmer group level, and problems on technology adoption. The feasibility study indicates that dairy farming in Banyudono is feasible to run, even without biogas processing. Nevertheless, to provide energy for the community, biogas processing is promising. This study finds that biogas processing brings more benefit to independent farmers than members of dairy farmer groups, which is possibly related to the group's problem of management. Therefore, an improvement in its management is recommended that more members enjoy the benefit of biogas processing.

\section{References}

Ahlberg-eliasson, K., Nadeau, E., \& Levén, L., Schnürer, A. (2017). Production efficiency of Swedish farmscale biogas plants, Biomass and Bioenergy, 27-37. https://doi.org/10.1016/j.biombioe.2016.12.002

Andrawina, K. E., Zulfikri, A., Maranatha, T.RR., Handayani, W. (2019). Women and Wastes : Study on the participation of housewives on plastic waste management in Kecandran, Salatiga, Indonesia, Sustinere 3(3), 199-212. https://doi.org/10.22515/sustinere.jes.v3i3.90

Arsanti, V. (2018). Persepsi Masyarakat Terhadap Lingkungan Kandang Sapi di Kelurahan Bener Kecamatan Tegalrejo Yogyakarta. Media Komunikasi Geografi, 19(1), 63-75. https://doi.org/http://dx.doi.org/10.23887/mkg.v19i1.13901

Bößner, S., Devisscher, T., Suljada, T., Ismail, C. J., Sari, A., \& Mondamina, N. W. (2019). Biomass and Bioenergy Barriers and opportunities to bioenergy transitions : An integrated, multi-level perspective analysis of biogas uptake in Bali. Biomass and Bioenergy, 122(January), 457-465. https://doi.org/10.1016/j.biombioe.2019.01.002

Chadwick, D., Sommer, S., Thorman, R., Fangueiro, D., Cardenas, L., Amon, B., Misselbrook, T. (2011). Manure Management: Implications for Greenhouse Gas Emissions. Animal Feed Science and Technology, 116167, pp.514-531. https://doi.org/10.1016/j.anifeedsci.2011.04.036

Du, Y., Wang. X., Brombal, D., Moriggi, A., Sharpley, A., \& Pang, S. (2018). Changes in Environmental Awareness and Its Connection to Local Environmental Management in Water Conservation Zones : The Case of Beijing, China. Sustainability, 10(6), 2087. https://doi.org/https://doi.org/10.3390/su10062087

Fischer, E., \& Qaim, M. (2014). Smallholder Farmers and Collective Action : What Determines the Intensity of Participation? Journal of Agricultural Economics, 65(3), 683-702.

Gabisa, E. W., \& Gheewala, S. H. (2019). Biomass and Bioenergy Potential, environmental, and socioeconomic assessment of biogas production in Ethiopia : The case of Amhara regional state. Biomass and Bioenergy, 122(January), 446-456. https://doi.org/10.1016/j.biombioe.2019.02.003

Geissdoerfer, M., Savaget, P., Bocken, N. M. P., \& Jan, E. (2017). The Circular Economy: A new sustainability paradigm? Journal of Cleaner Production, $143, \quad 757-768$. https://doi.org/10.1016/j.jclepro.2016.12.048

Harianingsih, I \& Riwayati, I. H. (2018). Pelatihan Pembuatan Keju Lunak Alami dan Produk Olahannya Bagi Peternak Sapi di Desa Pengging Kecamatan Banyudono Boyolali. Jurnal Pengabdian Masyarakat Unwahas, 3(2), 26-29. https://doi.org/http://dx.doi.org/10.31942/abd.v3i2.2499

Ham, M., Mrčela, D., \& Horvat, M. (2016). Insights for Measuring Environmental Awareness. Ekonomski Vjesnik, 29(1), 159-176. https://hrcak.srce.hr/ojs/index.php/ekonomski-vjesnik/article/view/3661.

Herdian, H., Julendra, H., Febrisiantosa, A., Damayanti, E., Wahono, S.K., Karimy, M.F., Istiqomah, L. (2013). Evaluasi Penerapan Sistem Pertanian Terpadu Berbasis Sapi Potong di Delapan Lokasi dengan Letak Geografis yang Berbeda. Proceedings of National Seminar and Workshop on Increasing Innovation in Overcoming Poverty - LIPI. 
International Labor Office. (2013). Produksi Bersih (Meningkatkan Produktivitas). Jakarta: ILO.

KPTT Susu Makmur. 2016. Buku Profil KPTT Susu Makmur. [Unpublished].

Lakitan, B. (2019). Double track strategy for agriculture development in indonesia: facilitating millennial generation and improving livelihood of smallholder farmers. In : Herlinda, S., Lakitan, B., Budiharjo, W., Effendi, I., Adriani, D., Wijayanti, M., Anggana, M., Wulandari, Yonarta, D., Nunilahwati, H., Tanbiyaskur (Editor). Prosiding Seminar Nasional Lahan Suboptimal Tahun 2019, (Palembang, 4-5 September), 1-8. Palembang: Unsri Press.

La Ferrara, E. (2002). Inequality and Group Participation: Theory and evidence from rural Tanzania. Journal of Public Economics 85: 235-273.

Liun, E. (2015). Profil dan Tren Permintaan Energi di Indonesia. in Udiyani, P.M. et al (Eds.) Prosiding Seminar Nasional Teknologi Energi Nuklir 2015 v.1, pp.16-24. Jakarta: Badan Tenaga Nuklir Nasional (BATAN).

Maktub, Z. A., Hidayati, S., Utomo, T.P., Suroso, E. (2019). Analisis Potensi dan Kelayakan Finansial pada Agroindustri Biogas Menggunakan Covered Lagoon Anaerobic Reactor Termodifikasi A nalysis of Financial and Potential Feasibility in Biogas Agroindustry using Modified Covered Lagoon Anaerobic Reactor. Jurnal Teknologi Dan Manajemen Agroindustri, 8(3), 218-226. https://doi.org/https://doi.org/10.21776/ub.industria.2019.008.03.6

Mateo-Sagasta, J., Zadeh, S.M., Turral, H. (2017). Water pollution from agriculture: a global review. Rome: FAO - IWMI.

Mei, N.S., Wai, C.W., \& Ahamad, R. (2016). Environmental Awareness and Behaviour Index for Malaysia. Procedia - Social and Behavioral Sciences, 222(07), 668-675. https://doi.org/10.1016/j.sbspro.2016.05.223.

Ministry of National Development Planning of Indonesia. (2019). Roadmap of SDGs Indonesia: A highlight. Jakarta: Ministry of National Development Planning of Indonesia.

Mohammed, M., Egyir, I. S., Donkor, A. K., Amoah, P., Nyarko, S., Boateng, K. K., Ziwu, C. (2016). Feasibility study for biogas integration into waste treatment plants in Ghana. Egyptian Journal of Petroleum, 26(3), pp. 695-703. https://doi.org/10.1016/i.ejpe.2016.10.004.

Muradin, M., Lechman, K.J., and Foltynowicz, Z. (2018). Evaluation of Eco-Efficiency of Two Alternative $\begin{array}{lllll}\text { Agricultural Biogas Plants. Applied } & \text { Sciences, }\end{array}$ https://doi.org/https://doi.org/10.3390/app8112083

Nurhayati, I.S., \& Widiawati, Y. (2017). Emisi Gas Rumah Kaca dari Peternakan di Pulau Jawa yang Dihitung dengan Metode Tier-1 IPCC ( Greenhouse Gas Emissions from Livestock in Java Island Calculated by IPCC Tier-1 Method). Prosiding Seminar Nasional Teknologi Peternakan dan Veteriner 2018, pp. 292300. http://repository.pertanian.go.id/handle/123456789/5019.

Nurmalina, R. \& Riesti, S. (2010). Analisis Biaya Manfaat Pengusahaan Sapi Perah dan Pemanfaatan Limbah Untuk Menghasilkan Biogas Pada Kondisi Risiko (Studi Kasus: Kecamatan Cisarua dan Megamendung, Kabupaten Bogor, Jawa Barat). Jurnal Pertanian, 1(1), 17-34.

Purnaningsih, N., Anugrah, I.S., Sarwoprasodjo, S., Suradisastra, K. (2014). Sistem Pertanian Terintegrasi Simantri: Konsep, Pelaksanaan dan Perannya dalam Pembangunan Pertanian di Provinsi Bali (Integrated Agriculture System ( Simantri ): Its Concept , Implementation, and Role in Agricultural Development in Bali Province). Forum Penelitian Agro Ekonomi: Pusat Sosial Ekonomi Dan Kebijakan Pertanian, 32(2), 157-176.

Sandyatma, Y. ., \& Hariadi, S.S. (2012). Partisipasi Anggota Kelompok Tani dalam Menunjang Efektivitas GAPOKTAN pada Kegiatan Penguatan Lembaga Distribusi Pangan Masyarakat di Kabupaten Bogor. Jurnal Kawistara, 2(3), 225-328.

Septiani, B. A., Arianie, D. M., Risman, V.F.A, Handayani, W., Kawuryan, I.S.S. (2019). Pengelolaan Sampah Plastik di Salatiga: Praktik dan Tantangan. Jurnal Ilmu Lingkungan, 17(1), 90-99. https://doi.org/10.14710/jil.17.1.90-99

Suhartanto, B., Agus, C., Agus, A. (2015). Pengembangan Sistem Pertanian Skilus-Bio Terpadu untuk Peningkatan Produktivitas Ternak Sapi pada Kelompok Ternak Desa Margoagung, Sayegan, Sleman, Yogyakarta. Jurnal Pengabdian Kepada Masyarakat, 1(1), 96-108. 
https://doi.org/https://doi.org/10.22146/jpkm.16957

Sunarto, D., \& Luthfianto, E. M. (2012). Pengaruh macam limbah organik dan pengenceran terhadap produksi biogas dari bahan biomassa limbah peternakan ayam. Bioteknologi, 9(1), 18-25. https://doi.org/10.13057/biotek/c090104

Syamsu, J.A., Ali, H.M., Yusuf, M. (2010). Prospek Pengembangan Peternakan Berkelanjutan Melalui Sistem Integrasi Tanaman-Ternak Model Zero Wate si Sulawesi Selatan. Balai Penelitian Ternak: Badan Litbang Pertanian - Kementrian Pertanian, (3), 1-10. Retrieved from http://balitnak.litbang.pertanian.go.id/index.php/publikasi/category $/ 30-3$ ?download=516\%3A3

Tonda, E., \& Susan, C. (2015). Technology challenges and tools for the implementation of the water-related sustainable development goals and targets. [Paper presented in 2015 UN Water Annual Zaragosa Conference]

https://www.un.org/waterforlifedecade/waterandsustainabledevelopment2015/pdf/Water_techno logy_tool_paper_final.pdf (retrieved on July 2, 2020)

United City and Local Goverment. (2018). Tujuan Pembangunan Berkelanjutan yang Perlu Diketahui oleh Pemerintah Daerah. Jakarta: United City and Local Government Asia Pacific.

Usack, J. G., Wiratni, W., \& Angenent, L. T. (2014). Improved Design of Anaerobic Digesters for Household Biogas Production in Indonesia: One Cow, One Digester, and One Hour of Cooking per Day. The Scientific World Journal, 2014, pp. 1-8. https://doi.org/10.1155/2014/318054

Wahyuni, S. \& Amiruddin, S. (2009). Analisis Kelayakan Pengembangan Biogas sebagai Energi Alternatif Berbasis Individu dan Kelompok Peternak. Jurnal Manajemen Pengembangan Industri Kecil Menengah, $4(2), 217-224$.

Wijayanto, A. (2012). Pemberdayaan Masyarakat di Lima Desa Berproduksi Beras Rendah di Kecamatan Banyudono Kabupaten Boyolali. Journal of Sustainable Agriculture, 27(2). https://doi.org/https://doi.org/10.20961/carakatani.v27i2.14274

Yin, R. K. (2003). Case Study Research: Design and Methods. Thousand Oaks: SAGE. 